\title{
Potential of orchid as antifungal agent resources: a scoping review
}

\author{
Furqi Sholekhatun Sityardi' ${ }^{1}$, Sufi Desrini ${ }^{2 *}$ \\ ${ }^{1}$ Student of Faculty of Medicine, Universitas Islam Indonesia, ${ }^{2}$ Departement of Pharmacology, \\ Faculty of Medicine, Universitas Islam Indonesia
}

https://doi.org/10.22146/ijpther.2325

Submitted: 07/08/2021

Accepted : 30/09/2021

Keywords:

orchid;

antifungal activity;

C. albicans;

T. rubrum;

Gavilea lutea;

\begin{abstract}
In 2017, one billion people suffer from fungal diseases with 11.5 million people contracted life-threatening infection and 1.5 million death per year. Orchid is a plant that grows in tropical and sub-tropical countries, the same places where fungal infection occurrence is high. On previous studies reported that orchid contains alkaloids and polyphenols such as flavonoid, and phenol acid. The review aimed to identify the orchid as a potential antifungal resource. A scoping review was used. The type of articles reviewed were original articles obtained from five electronic journal databases published within 2012-2021. Three articles reported similar result which was that orchid extract has a significant antifungal activity although the part of plant used was different, ranging from the root, to the leaf. Two articles reported a specific antifungal activity against Candida albicans while the remaining one against Trichophyton rubrum. In conclusion, the root, leaf, branch, and flower extracts of orchid is potential antifungal resources.
\end{abstract}

\begin{abstract}
ABSTRAK
Pada 2017, satu miliar orang terinfeksi jamur dengan 11,5 juta infeksi yang mengancam jiwa dan 1,5 juta menyebabkan kematian. Anggrek adalah tanaman yang tumbuh di negara tropis dan sub-tropis tempat kejadian infeksi jamur tinggi. Pada penelitian sebelumnya dilaporkan anggrek mengandung alkaloid dan polifenol seperti flavonoid dan asam fenolik. Tinjauan ini bertujuan mengidentifikasi anggrek sebagai sumber antijamur yang potensial. Scoping review digunakan dalam tinjauan ini. Jenis artikel yang ditelaah adalah artikel hasil penelitian yang diperoleh dari lima database jurnal elektronik yang dipublikasi 2012-2021. Tiga artikel melaporkan hasil yang sama yaitu anggrek mempunyai aktivitas antijamur meskipun bagian tanaman yang digunakan berbeda dari akar sampai daun. Dua artikel melaporkan aktivitas antijamur spesifik melawan Candida albicans sedangkan satunya melawan Trichophyton rubrum. Dapat disimpulkan, ekstrak akar, daun, batang dan bunga anggrek merupakan sumber antijamur potensial.
\end{abstract}

\section{INTRODUCTION}

Fungi are heterotrophic and eukaryotic microorganisms in the form of cells or branched filaments with chitin and glucan in their cell walls. ${ }^{1}$ Fungi are one of the causes of infectious diseases in tropical countries with high humidity. Indonesia is one of the tropical countries with a hot and humid climate favorable for fungal growth, increasing fungal infection diseases incidence. ${ }^{2}$ Infection is a health problem that is difficult to eradicate. $^{3}$ In 2017, one billion people contracted a fungal infection, with 11.5 million peoplecontractedlife-threatening infection and 1.5 million death per year. ${ }^{4}$ Incidence of fungal infection diseases is higher in men compared to a woman. ${ }^{5}$ Fungal infection disease can be classified into two groups, superficial infection and systemic infection. ${ }^{6}$

Superficial fungal infection is a fungal infection that affects the surface of the body such as skin, hair, and nails. ${ }^{7}$ The superficial fungal infection 
affects approximately $20-25 \%$ of the world's population and is one of the most common types of infection in humans. ${ }^{8}$ Superficial fungal infection includes dermatophytosis, pityriasis versicolor, candidiasis superficialis, and otomycosis. ${ }^{9}$ Based on ten-year research from 2008 to 2018 in North East China, there were three most common dermatophytosis which were tinea pedis $(28.62 \%)$, tinea cruris $(18.94 \%)$, and tinea corporis (17.45\%) and three most common cause of human fungal infections were Trichophyton rubrum (48.65\%), T. mentagrophytes (16.14\%) and Candida sp. (17.40\%). ${ }^{5}$

The most frequent infection sites of T. rubrum include foot, inguinal, axilla, scalp, and nail. This infection causes mild to moderate dermatological symptoms with a variety of severity. The variation of dermatological symptoms is due to the level of immune response towards the microorganism. Trichophyton rubrum causes diseases such as tinea pedis, tinea cruris, and tinea corporis. Around 80\% of patients with acute dermatophytosis respond well to topical antifungal treatment, while the other $20 \%$ develop chronic dermatophytosis resistant to antifungal treatment. The occurrence of dermatophytosis is affected by many factors such as personal hygiene, tight clothing, socioeconomic status, and chronic illnesses (immunosuppression) like HIV. ${ }^{10}$. Clinically, $T$. rubrum is resistant to the most frequently used treatment for the infection, terbinafine. It is also known to be resistant to other modern antifungals like fluconazole, itraconazole, and ketoconazole. This fungus resists the therapies mentioned above by increasing the efflux of the drug. ${ }^{11}$

Systemic fungal infection is a fungal infection that affects deeper tissues and organs. ${ }^{7}$ Systemic fungal infections, including Coccidioidomycosis, Blastomycosis, Talaromycosis, and Candidiasis, are clinical severe conditions. ${ }^{12}$ invasive disease can occur in immunocompetent individuals if the exposure dose is high or with primary (dimorphic Coccidioidomycosis is caused by a pathogenic fungus, Coccidioides immitis. It affects the lungs and produces a pneumonia-like symptom similar to pneumonia caused by other etiologies, which is coughing with pleuritis. ${ }^{12}$ Blastomycosis is a systemic fungal infection that affects the lungs, bones, and nervous system. The causes of blastomycosis are Blastomyces dermatitidis dan $B$. brasieliensis. The symptoms of blastomycosis is similar to that of tuberculosis. ${ }^{13}$ Talaromycosis, caused by Talaromyces marneffei is one of the most common opportunistic infections in acquired immune deficiency syndrome (AIDS) patients. ${ }^{14}$ Talaromycosis may also affect healthy people and is widely spread in South Asia and Southeast Asia, particularly in the north part of Thailand and the south part of China. This infection often manifests as a lung infection associated with skin lesions. ${ }^{12}$ Candidiasis is a fungal infection that can affect both superficial and deep parts of the body, such as the heart, lungs, mucosal layer, and vagina, ${ }^{15}$

Fungal infections can also be classified based on the type of fungi which are opportunistic fungi and pathogenic fungi. ${ }^{7}$ Opportunistic fungi cause a disease in the presence of predisposition factors like immune suppression, metabolic disorders, and drugs such as corticosteroid and antibiotic consumption. Some examples of opportunistic fungi are Candida spp, Aspergillus spp, and Mucor spp. ${ }^{7}$

Candida is naturally a normal flora of the human body. However, candidiasis may occur in the presence of predisposition factors such as immune suppression, HIV-AIDS, and endocrine system disorders. Morphologically, C. albicans has three forms which are blastospores/yeast, hyphae, and pseudohyphae. Candida albicans reproduce by blastospores which are spores emerging from the budding. Candida albicans is dimorphic, and aside from yeast and pseudohyphae, it is also able to produce true hyphae. ${ }^{16}$ The growth of $C$. albicans is optimum at $37{ }^{\circ} \mathrm{C}$ in both aerobic or anaerobic conditions. In aerobic conditions, $C$. 
albicans require $98 \mathrm{~min}$ to grow and $248 \mathrm{~min}$ in anaerobic conditions. Acidic condition is more favorable for candida growth compared to neutral or caustic conditions. ${ }^{17}$ Fluconazole is the most frequently prescribed treatment for oropharyngeal and vulvovaginitis caused by candida. Despite that, a research conducted by Peron et al., ${ }^{18}$ this study aimed to perform an antifungal susceptibility surveillance with the C.albicans bloodstream isolates and to characterize the fluconazole resistance in 2 non-blood C.albicans isolates by sequencing ERG11 gene. The study included 147 C. albicans bloodstream samples and 2 fluconazole resistant isolates: one from oral cavity (LIF 12560 fluconazole MIC: $8 \mu \mathrm{g} / \mathrm{mLC}$. albicans was shown to have developed resistance towards antifungal medications in the azole group. Long-term treatment with fluconazole can cause mutation, leading to treatment failure in candidiasis.

Pathogenic fungus is a type of fungi that cause diseases in healthy humans without any predisposition factor. ${ }^{7}$ Some pathogenic fungi include $C$. immitis, Histoplasma capsulatum, Sporothrix schenkii, Paracoccidioides brasiliensis, $B$. dermatiditis, and Cryptococcus neoformans. ${ }^{19}$ Histoplasmosis is caused by inhaling air that contains microscopic spores of Histoplasma capsulatum. ${ }^{20}$ This fungus species lives on highly nitrogenous soil contaminated with bat or chicken droppings. Symptoms of histoplasmosis occur gradually within a few weeks. The symptoms include weight loss, malaise, mild fever, cough, and breathing difficulty. Within 2-6 months, the symptoms usually resolve by themselves. However, the symptom could progress into hemoptysis with a large quantity of blood. In this case, antifungal medication could be used to diminish the infecting fungi, but it could not repair the damaged tissues. Paracoccidioidomycosis and Cryptococcosis are caused by inhalation of $P$. brasiliensis spores and $C$. neoformans, respectively. It presents as a nonspecific clinical appearance in the lungs and may spread into other organs. This fungus species lives on highly nitrogenous soil contaminated with bat or chicken droppings and reproduces by budding or blastospores. ${ }^{21}$

The abundance of diseases caused by fungal infection have prompted people, especially those working in health field, to make developments in antifungal agents. Nowadays, there are many kinds of antifungal agent freely sold in the markets, however, that does not ensure that fungal infection diseases will be subdued. Pharmacological therapy for fungal infection is divided into five groups, azoles, allylamines, polyenes, echinocandins, and others. ${ }^{22}$ They have some side effects, most frequently gastrointestinal problems such as dyspepsia, nausea, vomiting, and diarrhea. ${ }^{23}$ Those side effects have caused several people to choose traditional remedies to fight antifungal infection diseases instead of the modern antifungal agents. ${ }^{24}$

Indonesia has excellent knowledge of using plants as health maintenance and disease treatment alternative. ${ }^{25}$ One of the plants used for traditional medicine is the orchid. ${ }^{26}$ The use of orchids as traditional medicine has been reported in China, Japan, Korea, Taiwan, and Tibet. The local people of India, Sri Lanka, Papua New Guinea, Malaysia, and Indonesia utilize parts of the orchid plant such as the root, rhizome, stem, or all parts of the plant as a treatment for cough, ear pain, ringworm, internal bleeding, and wounds caused by infection. ${ }^{27}$ Some chemical components found in large quantities in an orchid are alkaloids, flavonoids, bibenzyl derivates, phenanthrenes, and terpenoids. ${ }^{27}$

Alkaloids can suppress the work of enzymes to synthesize cells protein, causing metabolism disruption of the fungal cell, leading to cell death due to damage in the fungal cell wall structure. Furthermore, alkaloids can damage mitochondria, depleting the fungal cells of energy, resulting in cell death. In other cases, alkaloids can play a role as an anticancer by producing reactive oxygen species (ROS) and induce apoptosis in cancerous cells. ${ }^{28-30}$ Besides alkaloid, flavonoid exerts 
antifungal property by interacting with the DNA of the fungus, disrupting fatty acid synthesis. This mechanism is also the specific target of the development of antifungal agents. Besides that, the hydroxyl ion in flavonoids can change the distribution process of nutrition and organic components which causes toxicity to the fungal cell. ${ }^{31,32}$ Meanwhile, bibenzyl (dihydrostilbenoid) is reported to have antimitotic and antileukemia activity. There is also ongoing research on the potential of bibenzyl as a cytotoxic agent on cancer cells. ${ }^{33}$ The other component, phenanthrene, is found in vascular plants, particularly in Orchidaceae plants. ${ }^{34}$ Phenanthrene has been proven to have biological activities such as anticancer, antimicrobe, spasmolytic, antiallergy, antifungal, and antiinflammation. ${ }^{35}$ Terpenoid has almost similar effects with phenanthrene which are antitumor, antiinflammation, antibacterial, antivirus, antimalaria, increasing transdermal absorption, prevent and treat cardiovascular diseases, and hypoglycemic activities. ${ }^{36}$

An article by Gutiérrez ${ }^{27}$ light intensity and growth parameters. Namely, net assimilation rate, relative growth rate, leaf weight ratio, leaf area ratio and specific leaf area for oregano (Origanum onites L. has discussed the potential of orchid plants as an antifungal. However, it discussed antifungal properties towards fungi that infect plants and not humans. Based on the findings above, we will investigate the potential of orchid plants as an antifungal agent. To the researchers' knowledge, there is currently no scoping review article discussing orchid plants' potential as an antifungal for human fungal infections. Therefore, this review aimed to evaluate some literature about the potential ability of orchid as potential antifungal recources.

\section{MATERIAL AND METHODS}

\section{Article criteria}

The articles included in this review were selected based on the inclusion and exclusion criteria. The inclusion criteria were 1) original article published between $2012-2021$; 2) the article was written in English; 3) the subject of the research was fungi that infect humans; 4) the plants used in the research had been identified or determined; 5) the orchid plants used were within the family Orchidaceae; and 6). the main outcomes of the research were inhibition zone diameter, inhibition strength, minimum inhibitory concentration (MIC), or minimum fungicidal concentration (MFC). Incomplete articles and articles only containing abstracts were excluded.

\section{Information sources}

The data for this research were accessed from PubMed, Science Direct, Springer Link, Wiley, dan Taylor and Francis. Those databases were chosen because of their easiness to access with no cost needed as they can be accessed using the researchers' Universitas Islam Indonesia accounts.

\section{Article searching strategy}

The articles were searched using keywords that were under the formulation of this research problem. The keywords were obtained using the PICO method seen in TABLE 1.

TABLE 1. PICO Formulation

\begin{tabular}{lcc}
\hline Question part & $\begin{array}{c}\text { Question } \\
\text { Term }\end{array}$ & Synonyms \\
\hline Population & Fungi & Fungal/fungi/fungus \\
Intervention & Orchid & Orchid/Orchidaceae \\
Comparison & - & - \\
Outcome & Antifungal & Antifungal/Antifungi \\
\hline
\end{tabular}




\section{Article selection process}

The articles were selected based on the inclusion criteria. The process were conducted according to the Preferred Reporting Items for Systematic Reviews and Meta-Analyses Extension for Scoping Reviews (PRIMA-ScR) statement. ${ }^{37}$

The scoping review process based on PRIMA-ScR followed several steps, which were a) identification, article searching process using the pre-determined keywords in the aforesaid information sources; b) screening, exclusion process of identical articles obtained from different information sources; c) eligibility, exclusion process of articles that can not be fully accessed; and d) included, selection process to choose tobe-reviewed articles based on the predetermined inclusion and exclusion criteria. $^{38}$

\section{Data extraction}

The data extraction process extended from identifying the articles to study the content of the articles to gain information according to the aim of this research. ${ }^{39}$ The Components that were included in the data extraction TABLE were reference, plant species, parts of plant utilized, extraction method, fractionation method, compounds found in the plant, research method, the result of the research and conclusion.

\section{Data item}

Data items used in this research were: (a) characteristics of obtained journals, including authors, publishing year, plant species, parts of plant utilized, extraction and fractionation method, fungus species, and methods used to determine antifungal activity; (b) main outcomes of the study, which were inhibition zone diameter, inhibition strength, MIC, MFC, and active compounds that have antifungal activities.

\section{RESULTS}

\section{Selection result of sources of evidences} The article searching process was conducted by inputting the keywords based on PICO analysis into five databases: PubMed, Science Direct, Springer Link, Wiley, and Taylor and Francis. There were 712 articles obtained from the mentioned databases (TABLE 2).

TABLE 2. Article searching result by using keywords based on PICO analysis

\begin{tabular}{ll}
\hline Databases & \multicolumn{1}{c}{ Result } \\
\hline \multirow{3}{*}{ PubMed } & $((((($ fungi) OR (fungal)) OR (fungus)) AND (orchid)) OR (orchidaceae)) \\
& AND (antifungal)) OR (antifungi) \\
& $=63$ articles \\
& fungal or fungi or fungus and or orchid or orchidaceae and or antifun- \\
gal or antifungi & $=189$ articles \\
& $((((($ fungi) OR (fungal)) OR (fungus)) AND (orchid)) OR (orchidaceae)) \\
& AND (antifungal)) OR (antifungi) \\
& $=108$ articles \\
Wiley & fungal or fungi or fungus and or orchid or orchidaceae and or antifungal \\
& or antifungi \\
& $=137$ articles \\
Science Direct & [All: fungal] OR [All: fungi] OR [[All: fungus] AND [All: orchid]] OR [[All: \\
& orchidaceae] AND [All: antifungal]] OR [All: antifungi] AND [in Journal] \\
& $=215$ articles
\end{tabular}


Based on the Preferred Reporting Items for Systematic Reviews and Meta-Analyses Extension for Scoping Reviews (PRIMA-ScR) statement, the obtained articles were then screened for duplicates. There were 20 duplicated articles excluded. Therefore only 692 articles were processed into the next step. On the screening for incomplete articles, 21 articles were excluded. There were 157 more articles excluded on the next process as those did not fall into the original article category. On the title and abstract selection process, 500 articles were excluded as those are not relevant to the aim of this research. Thus, 14 articles were analyzed entirely. Among the 14 articles, 9 of those discussed antifungal activity of orchid plants to fungi that infect plants instead of humans; thus, those articles were excluded. Another article was excluded as it does not discuss the compound with antifungal activity, and another article was excluded as it does not use inhibition zone, MIC, and MFC as the indicator of antifungal activity. In conclusion, there were three articles used in this scoping review.

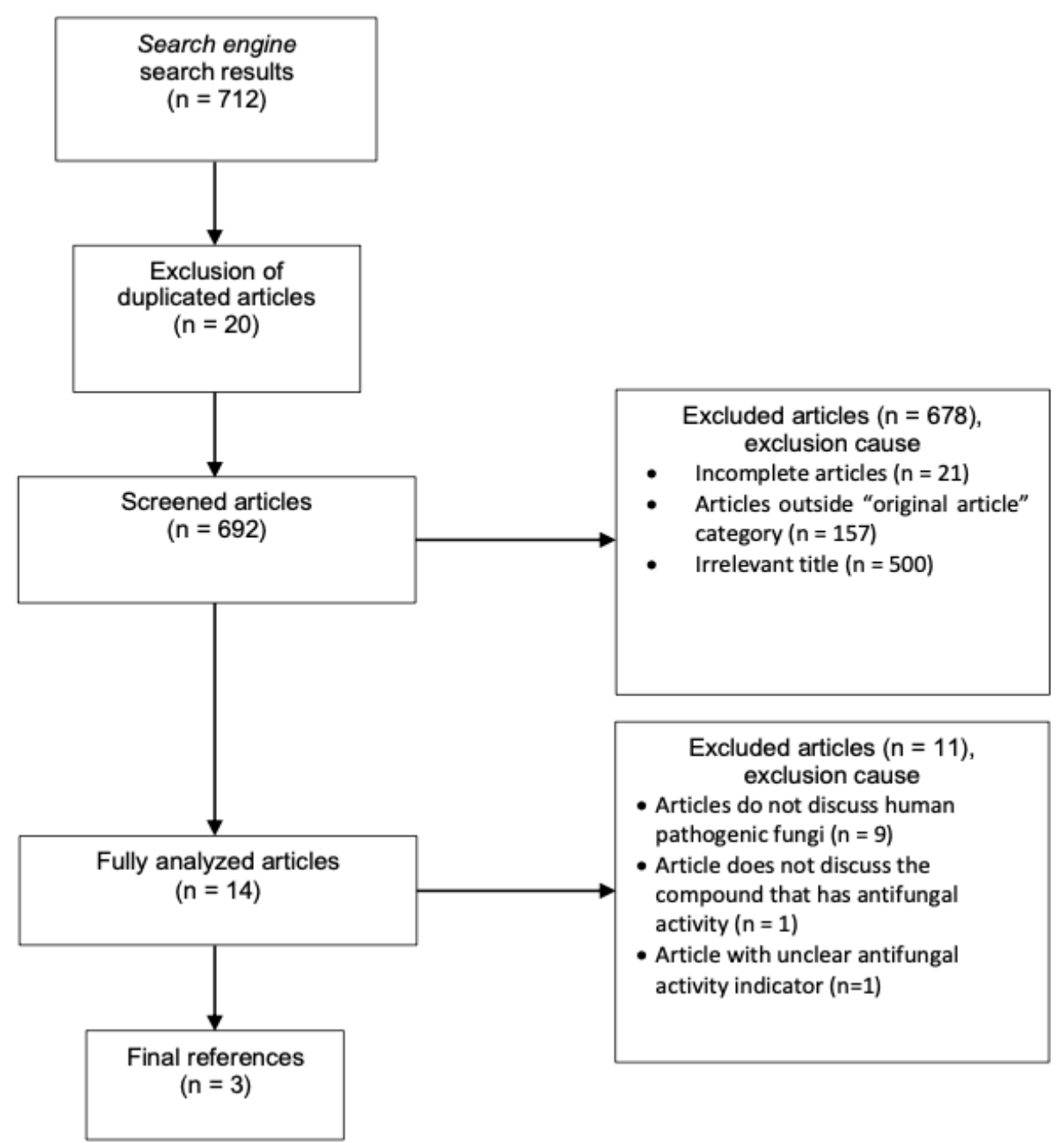

FIGURE 1. Flowchart diagram of article selection process

\section{Source of evidence characteristics}

Information obtained from the three analyzed articles is relevant to the research question and aim of this scoping review: plant species, part of the plant used, extraction and fractionation, the compound found in the plant, and the method to determine antifungal activities (TABLE 3). 
TABLE 3. Result of source of evidence characteristics study

\begin{tabular}{|c|c|c|c|c|c|c|}
\hline Refrence & Species & $\begin{array}{c}\text { Plant } \\
\text { part }\end{array}$ & $\begin{array}{l}\text { Extraction } \\
\text { Method }\end{array}$ & $\begin{array}{l}\text { Fractination } \\
\text { Method }\end{array}$ & Compound & $\begin{array}{l}\text { Research } \\
\text { Method }\end{array}$ \\
\hline Yoshikawa et al..$^{40}$ & $\begin{array}{l}\text { Cymbidium } \\
\text { Great Flower }\end{array}$ & Root & Maceration & $\begin{array}{l}\text { Column } \\
\text { chromatography }\end{array}$ & $\begin{array}{l}\text { Ephemeranthoquinone } \\
\text { C Marylaurencinol } \\
\text { C Marylurencinol D } \\
\text { 2,4,7,8-tetramethoxy-3- } \\
\text { hydroxy-phenanthrene } \\
\text { calaquinone A }\end{array}$ & Disk-diffuson \\
\hline Cretton et al. ${ }^{42}$ & Gavilea lutea & $\begin{array}{c}\text { Aerial } \\
\text { parts }\end{array}$ & Maceration & $\begin{array}{l}\text { Flash } \\
\text { chromatography }\end{array}$ & $\begin{array}{l}\text { Kaempferol-3-7-di-o- } \\
\text { glucoside kaempferol-3- } \\
\text { O-glucoside batatasin III } \\
\text { Gavilein Isohircinol }\end{array}$ & TLC plate \\
\hline Fang et al. ${ }^{41}$ & $\begin{array}{l}\text { Bulbopyllum } \\
\text { ratusculum }\end{array}$ & Roots & Soxhlet & $\begin{array}{l}\text { Column } \\
\text { chromatography }\end{array}$ & $\begin{array}{l}\text { Ratusiussines A Ratusiuss- } \\
\text { ines B } \\
\text { Ratusiussines C } \\
\text { Dihydroconyferyl dihydro- } \\
\text { p-coumarate Methyl } \\
\text { 3-(4-hydroxyphenyl) } \\
\text { propionate } \\
\text { 3-(4-hydroxyphenyl)- } \\
\text { propionic acid } \\
\text { dyhydroferulic acid methyl } \\
\text { 3-(4-methoxyphenyl) } \\
\text { propionate 3-(3,4-dime- } \\
\text { thoxyphenyl)-2-propenal- } \\
\text { Trans-p-coumaric acid } \\
\text { Dihydroconyferyl alcohol }\end{array}$ & $\begin{array}{l}\text { 96-well plates } \\
\text { microdilotion }\end{array}$ \\
\hline
\end{tabular}

\section{Result of each source of evidence}

Data extraction from the three selected articles showed a homogenous result which can be inferred that there are suitable antifungal activities of different kinds of orchid plants, as shown in TABLE 4.

TABLE 4. Result of each source of evidence

\begin{tabular}{lllcccc}
\hline Species & \multicolumn{1}{c}{ Active compound } & Microorganism & $\begin{array}{c}\text { Inhibition } \\
\text { Zone }(\mathrm{mm})\end{array}$ & $\begin{array}{c}\text { MIC } \\
(\mu \mathrm{g} / \mathrm{mL})\end{array}$ & MFC $(\mu \mathrm{g} / \mathrm{mL})$ & Reference \\
\hline C. Great Flower & Ephemer anthoquinone C & T. rubrum & 12.7 & TD & TD & Yoshikawa et al. ${ }^{40}$ \\
& Marylaurencinol C & T. rubrum & 15.7 & TD & TD & Cretton et al. ${ }^{42}$ \\
G. lutea & Gavilein & C. albicans & TD & 50 & TD & Ctusculum \\
B. Retusiusine B & C. albicans & TD & 16 & TD & Fang et al. ${ }^{41}$ \\
\hline
\end{tabular}

Notes: MIC (minimum inhibition concentration); MFC (minimum fungicidal concentration); TD (no data)

Yoshikawa et $a l^{40}$ isolated ephemeranthoquinone $\mathrm{C}$ dan marylaurencinol $C$ from methanol extract of the root of $C$. Great Flower against $T$. rubrum fungi and reported their antifungal activity against $T$. rubrum with the diameter of inhibition zone of $12.7 \mathrm{~mm}$ and $15.7 \mathrm{~mm}$ in concentration of $10 \mu \mathrm{g} /$ disk, respectively. The diameter of inhibition zone of ketoconazole as positive control in concentration of $10 \mu \mathrm{g} /$ disk was $16.7 \mathrm{~mm}$. Whereas, the methanol extract of the root of $C$. Great Flower had a low antibacterial effect against $B$. subtilis and high antibacterial activity against $K$. pneumoniae (Table 4 ). Cretton et $a .^{42}$ reported antifungal activity of new bibenzyl derivative 
(gavilein) isolated from methanol extract of $G$. lutea against $C$. albicans with minimum inhibitory quantity (MIQ) of $50 \mu \mathrm{g}$ (Table 4). This activity was better than miconazole as the positive control. Morover, gavilein exhibited a selective activity against Leishmania donovani with inhibitory concentration $\left(\mathrm{IC}_{50}\right.$ ) of $2.3 \mu \mathrm{g} / \mathrm{mL}$.

Fang et al. ${ }^{41}$ isolated 11 secondary metabolites form methanolic extract of $B$. retusculum and evaluated their activity against $C$. albicans and Escherichia coli and Bacillus subtilis. Among 11 the secondary metabolites, retusiusine $B$ exhibited active against $C$. albicans with a MIC value of $16 \mu \mathrm{g} / \mathrm{mL}$, whereas retusiusine $C$ exhibited against $E$. coli and B. subtilis with a MIC value of $64 \mu \mathrm{g} /$ $\mathrm{mL}$.

\section{Result synthesis}

All three of the analyzed articles showed antifungal activity against the fungus studied. Two out of three articles used $C$. albicans. There is a heterogeneity in terms of the plant species and part of the plant used in the analyzed articles. These results showed that antifungal activity in orchid plants is not specifically found in a certain part of the plant. The extraction method used may influence the isolation of the compounds from the extract. This explains the reason of one extract is separated into five compounds while the other is separated into 11 compounds.

The three analyzed articles showed that different compounds are found in different plant species; however, all the plant extract exhibited antifungal activities. Yoshikawa et $a .^{40}$ used inhibition zone diameter as an indicator to determine antifungal activity, whereas Cretton et al. ${ }^{42}$ used MIQ as the indicator, while Fang et al. ${ }^{41}$ used MIC.

\section{DISCUSSION}

The high prevalence of human fungal infection in tropical countries emerge the problems of the side effect and resistance of antifungal drugs leading to the need of new antifungal agents development. Medicinal plants are one of potential natural sources of new antifungal agents. In previous study, orchid plants have been investigated for their potential new antifungal agents. This scoping review was conducted to evaluate the potential of orchid plants as antifungal sources against human pathogenic fungi. Three reviewed articles showed different methods used to extract and isolate compounds from orchid plants. Two articles used silica gel chromatography, while the remaining used flash chromatography. ${ }^{40,42}$

Column chromatography is commonly used to separate natural active compounds due to its simplicity, high capacity, and low adsorbents like silica gel and macro resin cost. Silica gel is the most commonly used polar adsorbent in the phytochemical investigation, accounting for $90 \%$ of phytochemical separation. Compounds are retained by the silica gel via hydrogen bonds and dipole-dipole interactions. Therefore, polar compounds are retained longer in silica gel columns compared to nonpolar ones. ${ }^{43}$ This column chromatography process starts with putting the sample on top of the column containing several adsorbents, most commonly silica gel. The remaining column is then filled with a solvent or solvent mixture, which flows via adsorbent by gravitational force. The various compounds that will be separated pass through the column with different velocities and are then collected separately when the compounds come out from below the column. Unfortunately, the solvent moves slowly. The velocity of the compound in passing through the column depends on how much the adsorbent absorbs the compound. ${ }^{44}$ Yoshikawa et al. ${ }^{40}$ used the column chromatography with silica gel to isolate phenolic acid i.e. phenanthrene and phenylpropanoid (cinnamic acid) from the root of $C$. Great Flower. Furthermore, Fang et al. ${ }^{41}$ used the same method to isolate phenylpropanoid from $B$. retusculum.

Cretton et al. ${ }^{42}$ used a different method, flash chromatography, to isolate an active compounds. Flash 
chromatography is also a column chromatography but uses pressure from nitrogen..$^{5}$ The pressure is used to speed up the solvent flow and decrease the time needed to purify the sample. Around ten to fifteen min is needed to conduct the method. Two differences of flash chromatography with the conventional method are 1) silica gel particles are smaller (250-400 mesh); 2) as the solvent flow is limited due to small particles of the gas, pressurized gas (10-15 psi) is used to move the solvent through the column. The final result is a rapid chromatography with high resolution. ${ }^{44}$ Cretton et al. ${ }^{42}$ isolated bibenzyl derivate, glycosylated flavonoid, batatasin III, and isorchinol phenanthrene.

Analysis of the three articles regarding the antifungal activity of orchid extract showed inhibitory activity against the fungi tested. The inhibitory activity is measured in different indicators. Yoshikawa et $a .^{40}$ showed that methanol extract of $C$. Great Flower contains new compounds, phenanthrene and marylaurencinols $C$ which active against $T$. rubrum. New active compound belonging phenylpropanoid i.e. ephemeranthoquinone $\mathrm{C}$ was also reported. Phenanthrene, and its derivates have been found in vascular plants including orchid. The biological activities of these compounds have been reported such as antifungal and antiinflammatory. However, the mechanism of action and structural activity relationship of these phenanthrene is rarely reported.

Antifungal activity against $C$. albicans of gavilein belonging bisbenzyl derivative isolated from G. lutea was reported by Cretton et al. ${ }^{42}$ with MIQ of $50 \mu \mathrm{g}$. Some bibenzyl compounds are reported to have antimitotic, antileukemia and cytotoxic activities. ${ }^{33}$ Fang et al..$^{41}$ reported the antifungal activity of phenylpropanoid i.e. retusine $B$ isolated from $B$. retusculum extract against $C$. albicans with MIC of $16 \mu \mathrm{g} / \mathrm{mL}$.

\section{CONCLUSION}

In conclusion, orchid plants are sources of new potential antifungal agents. Further studies are needed to explore active compounds from orchid species which a lot of grow in tropical countries especially in Indonesia.

\section{ACKNOWLEDGEMENTS}

The authors would like to express gratitude to the Faculty of Medicine Universitas Islam Indonesia and other parties that has helped in the process of writing this scoping review.

\section{REFERENCE}

1. Gandjar I, O. Sjamsuridzal W, Ariyanti. Mikologi dasar dan terapan. Jakarta: Gramedia Pustaka; 2006.

2. Nagaral GV, Goud GKV, Sudha PJ. Prevalence of tinea corporis and tinea cruris in Chitradurga rural population. IP Indian J Clin Exp Dermatol 2018; 4(3):221-5.

https://doi.org/10.18231/25814729.2018.0047

3. Irmayanti VA, Izhar D. Hubungan pengetahuan, personal higien, dan sumber air bersih dengan gejala penyakit kulit jamur di Kelurahan Rantau Indah Wilayah Kerja Puskesmas Dendang, Kabupaten Tanjung Jabung Timur tahun 2013. Sci J 2013; 2(2):79-85.

4. Tudela JLR, Denning DW. Recovery from serious fungal infections should be realisable for everyone. Lancet Infect Dis 2017; 17(11):1111-3. https://doi.org/10.1016/S14733099(17)30319-5

5. Wang X, Ding C, Xu Y, Yu H, Zhang $\mathrm{S}$, Yang $\mathrm{C}$. Analysis on the pathogenic fungi in patients with superficial mycosis in the Northeastern China during 10 years. Exp Ther Med 2020; 20(6):281.

https://doi.org/10.3892/etm.2020.9411

6. Shields BE, Rosenbach M, BrownJoel Z, Berger AP, Ford BA, Wanat KA. Angioinvasive fungal infections impacting the skin: Background, epidemiology, and clinical 
presentation. J Am Acad Dermatol 2019; 80(4):869-80.e5.

https://doi.org/10.1016/j.jaad.2018.04.059

7. Gatot D. Infeksi jamur sistemik pada pasien immunocompromised. Sari Pediatri 2016; 3(4):242.

ht tp://dx.doi.org/10.14238/ sp3.4.2002.242-6

8. Ameen M. Epidemiology of superficial fungal infections. Clin Dermatol 2010; 28(2):197-201.

http://dx.doi.org/10.1016/j. clindermatol.2009.12.005

9. Rosida F, Ervianti E. Retrospective study: superficial mycoses. Berkala Ilmu Kesehat Kulit dan Kelamin 2017; 29:117-25.

http://dx.doi.org/10.20473/bikk. V29.2.2017.117-125

10. Blutfield MS, Lohre JM, Pawich DA, Vlahovic TC. The immunologic response to trichophyton rubrum in lower extremity fungal infections. J Fungi 2015; 1(2):130-7. https://doi.org/10.3390/jof1020130

11. Peres NTDA, Rossi A, Maranhão FCA, Martinez-Rossi NM. Dermatophytes: host-pathogen interaction and antifungal resistance. An Bras Dermatol 2010; 85(5):657-67.

https://doi.org/10.1590/s036505962010000500009

12. Rautemaa-Richardson R, Richardson MD. Systemic fungal infections. Medicine (United Kingdom) 2017; 45(12):757-62.

ht tps://d oi.org/10.1016/j . mpmed.2017.09.007

13. Lockhart SR, Guarner J. Emerging and reemerging fungal infections. Semin Diagn Pathol 2019; 36(3):177-81. ht tp s://doi.org/10.1053/j . semdp.2019.04.010

14. Limper AH, Adenis A, Le T, Harrison TS. Fungal infections in HIV/AIDS. Lancet Infect Dis 2017; 17(11):e334-43. http://dx.doi.org/10.1016/S14733099(17)30303-1

15. McCarty TP, Pappas PG. Invasive candidiasis. Infect Dis Clin North Am 2016; 30(1):103-24.

http://dx.doi.org/10.1016/j. idc.2015.10.013

16. Brooks GF. Mikrobiologi kedokteran
Jawetz, Melnick, \& Adelberg. EGC. 2013.

17. Biswas SK, Chaffin WLJ. Anaerobic growth of Candida albicans does not support biofilm formation under similar conditions used for aerobic biofilm. Curr Microbiol 2005; 51(2):100-4.

https://doi.org/10.1007/s00284-005-4552-3

18. Peron IH, Reichert-Lima F, BussoLopes AF, Nagasako CK, Lyra $\mathrm{L}$, Moretti ML, et al. Resistance surveillance in Candida albicans: a five-year antifungal susceptibility evaluation in a Brazilian University Hospital. PLoS One 2016; 11(7):0158126.

https://doi.org/10.1371/journal. pone. 0158126

19. Schwartz S, Kontoyiannis DP, Harrison T, Ruhnke M. Advances in the diagnosis and treatment of fungal infections of the CNS. Lancet Neurol 2018; 17(4):362-72.

http://doi.org/10.1016/S14744422(18)30030-9

20. Kim JY. Human fungal pathogens: why should we learn? J Microbiol 2016; 54(3):145-8.

https://doi.org/10.1007/s12275-0160647-8

21. Caceres A, Avila ML, Herrera ML. Fungal infections in pediatric neurosurgery. Childs Nerv Syst 2018; 34(10):1973-88.

https://doi.org/10.1007/s00381-018-3942-3

22. Apsari AS, Adiguna MS. Resistensi antijamur dan strategi untuk mengatasi. J Media Dermato Venerologica Indones 2013; 40(2):89-95.

23. Girois SB, Chapuis F, Decullier E, Revol BGP. Adverse effects of antifungal therapies in invasive fungal infections: review and metaanalysis. Eur J Clin Microbiol Infect Dis 2006; 25(2):138-49.

https://doi.org/10.1007/s10096-005-0080-0

24. Sari LORK. Pemanfaatan obat tradisional dengan pertimbangan manfaat dan keamanannya. Majalah Ilmu Kefarmasian 2006; 3(1):1-7. https://doi.org/10.7454/psr.v3i1.3394

25. Supardi S, Susyanty AL. Penggunaan obat tradisional dalam upaya 
pengobatan sendiri di Indonesia. Pusat Penelitian, Pengembangan Sistem dan Kebijakan Kesehatan Jakarta. 2010;

26. Paradiso R, Pascale SD. Effects of plant size, temperature, and light intensity on flowering of phalaenopsis hybrids in Mediterranean greenhouses. Sci World J 2014; 2014:420807. https://doi.org/10.1155/2014/420807

27. Gutiérrez RMP. Orchids: a review of uses in traditional medicine, its phytochemistry and pharmacology. J Med Plants Res 2010; 4(8):592-638. https://doi.org/10.5897/JMPR10.012

28. Elansary HO, Salem MZM, Ashmawy NA, Yessoufou K, El-Settawy AAA. In vitro antibacterial, antifungal and antioxidant activities of Eucalyptus spp. leaf extracts related to phenolic composition. Nat Prod Res 2017; 31(24):2927-30.

http://doi.org/10.1080/14786419.201 7.1303698

29. Dhamgaye S, Devaux F, Vandeputte P, Khandelwal NK, Sanglard D, Mukhopadhyay G, et al. Molecular mechanisms of action of herbal antifungal alkaloid berberine, in Candida albicans. Plos One 2014; 9(8):104554.

https://doi.org/10.1371/journal. pone.0104554

30. Kukula-Koch WA, Widelski J. Alkaloids. In: Mccreath SB and Delgoda R editors. Pharmacognosy: fundamentals, applications and strategy $1^{\text {st }}$ eds. Elsevier Inc.; 2017. 163-8.

http://doi.org/10.1016/B978-0-12802104-0.00009-3

31. Bitencourt TA, TakahasiKomoto $\mathrm{T}$, Marins M, Fachin AL. Antifungal activity of flavonoids and modulation of expression of genes of fatty acid synthesis in the dermatophyte Trichophyton rubrum. BMC Proc 2014; 8(Suppl 4):P53.

https://doi.org/10.1186/1753-6561-8S4-P53

32. Lima NM, Cursino-Hron LM, Lima AM, Souza JVB, de Oliveira AC, MarinhoJVN, etal. Antifungal activity of extracts and phenolic compounds from Deguelia duckeana. Brazilian J Pharmacogn 2018;28(6):697-702.

https://doi.org/10.1016/j.bjp.2018.08.004

33. Wang XL, Liu D, Xia YM, Cao XP, Pan XF. Ramberg backlund rearrangement approaches to the synthesis of natural bibenzyls. Chinese J Chem 2004; 22(5):467-72. https://doi.org/10.1002/cjoc.20040220515

34. Kovács A, Vasas A, Hohmann J. Natural phenanthrenes and their biological activity. Phytochemistry 2008; 69(5):1084-110.

h t tps://doi.org/10.1016/j . phytochem.2007.12.005

35. Yoshikawa K, Ito T, Iseki K, Baba C, ImagawaH,YagiY,etal.Phenanthrene derivatives from Cymbidium great flower marie laurencin and their biological activities. J Nat Prod 2012; 75(4):605-9.

https://doi.org/ 10.1021/np200788u

36. Yang W, Chen X, Li Y, Guo S, Wang Z, $\mathrm{Yu} X$. Advances in pharmacological activities of terpenoids. Nat Prod Commun 2020; 15(3):1-13.

https://doi.org/10.1177/1934578X20903555

37. Tricco AC, Lillie E, Zarin W, O’Brien $\mathrm{KK}$, Colquhoun $\mathrm{H}$, Levac $\mathrm{D}$, et al. PRISMA extension for scoping reviews (PRISMA-ScR): Checklist and explanation. Ann Intern Med 2018; 169(7):467-73.

https://doi.org/10.7326/M18-0850

38. Peters MDJ, Godfrey CM, Khalil H, McInerney P, Parker D, Soares CB. Guidance for conducting systematic scoping reviews. Int J Evid Based Healthc 2015; 13(3):141-6.

h t t p s://d o i.org/10.1097/ XEB.0000000000000050

39. Passavanti MB, Alfieri A, Caterina Pace M, Pota V, Sansone P, Piccinno $\mathrm{G}$, et al. Clinical applications of palmitoylethanolamide in pain management: protocol for a scoping review. Sys Rev 2020; 8(1):9.

https://doi.org/10.1186/s13643-0180934-z

40. Yoshikawa K, Baba C, Iseki $\mathrm{K}$, Ito $\mathrm{T}$, Asakawa $\mathrm{Y}$, Kawano $\mathrm{S}$, et al. Phenanthrene and phenylpropanoid constituents from the roots of Cymbidium Great 
Flower "Marylaurencin" and their antimicrobial activity. J Nat Med 2014; 68(4):743-7.

https://doi.org/10.1007/s11418-014-0854-8

41. Fang YS, Yang MH, Cai L, Wang JP, Yin TP, Yu J, et al. New phenylpropanoids from Bulbophyllum retusiusculum. Arch Pharm Res 2018; 41(11):1074-81. https://doi.org/10.1007/s12272-018-1067-6

42. Cretton S, Oyarzún A, Righi D, Sahib L, Kaiser M, Christen $\mathrm{P}$, et al. A new antifungal and antiprotozoal bibenzyl derivative from Gavilea lutea. Nat Prod Res 2017; 32(6):695-701. https://doi.org/10.1080/14786419.201 7.1338287

43. Zhang QW, Lin LG, Ye WC. Techniques for extraction and isolation of natural products: a comprehensive review. Chinese Med 2018; 13:20. https://doi.org/10.1186/s13020-018-0177-x 44. Roge AB, Firke SN, Kawade RM, Sarje SK, Vadvalkar SM. Brief review on: flash chromatography a. IJPSR 2011; 2(8):1930-7.

h t t p s://doi.org/10.13040/ IJPSR.0975-8232.2(8).1930-37

45. Stevens WC, Hill DC. General methods for flash chromatography using disposable columns. Mol Divers 2009; 13(2):247-52.

https://doi.org/ 10.1007/s11030-0089104-x 